\title{
Susceptibility of Baltic and East Atlantic salmon Salmo salar stocks to Gyrodactylus salaris (Monogenea)
}

\author{
T. A. Bakke ${ }^{1, *}$, P. D. Harris ${ }^{2}$, H. Hansen ${ }^{1}$, J. Cable ${ }^{3}$, L. P. Hansen ${ }^{4}$ \\ ${ }^{1}$ Zoological Museum, The Natural History Museums and Botanical Garden (NHM), University of Oslo, Oslo, Norway \\ ${ }^{2}$ Department of Continuing Education, University of Nottingham, Nottingham NG7 2RD, UK \\ ${ }^{3}$ School of Biosciences, Cardiff University, Cardiff CF10 3TL, UK \\ ${ }^{4}$ Norwegian Institute for Nature Research (NINA), PO Box 736, Sentrum, Oslo, Norway
}

\begin{abstract}
The susceptibility of a Baltic salmon stock Salmo salar (Indalsälv, central Sweden) to Norwegian Gyrodactylus salaris (Figga strain, central Norway) was experimentally tested and compared with previously obtained results on East Atlantic salmon (Lierelva, SE Norway). Contrary to expectation, the Baltic salmon, which had no prior exposure to this parasite strain, appeared almost as susceptible as the Norwegian salmon parr that naturally experience G. salaris-induced mortality. Individually isolated salmon of both stocks sustained G. salaris infections with little evidence of innate resistance. A few individuals of the Indalsälv stock controlled their infection from the beginning, but overall there was considerable heterogeneity in the course of infection in both stocks. On individual hosts, G. salaris growth rates declined steadily throughout the infection, a trend which was particularly marked amongst the Lierelva stock. On shoaling Lierelva fish, there was some evidence of reduced parasite population growth towards the end of the infection; this was not apparent in Indalsälv fishes. These results reflect a growing awareness that not all Baltic salmon may be resistant to Norwegian G. salaris, and that Norwegian and Baltic G. salaris strains may differ in virulence. Consequently, management decisions concerning this parasite-host system should be based upon the actual, and tested, susceptibility of stocks under consideration and not upon identification of stocks as either Atlantic or Baltic.
\end{abstract}

KEY WORDS: Gyrodactylus salaris $\cdot$ Host-specificity $\cdot$ Resistance $\cdot$ Salmonids Resale or republication not permitted without written consent of the publisher

\section{INTRODUCTION}

The ectoparasite monogenean Gyrodactylus salaris is epidemic on East Atlantic salmon Salmo salar in Norway and has devastated fish stocks over the last $25 \mathrm{yr}$ (Heggberget \& Johnsen 1982, Johnsen et al. 1999). Average density of salmon parr in infected rivers has been reduced by $86 \%$, leading to an annual loss of 250 to $500 \mathrm{t}$ of salmon (NOU 1999). The total cost now exceeds 500 million US dollars.

When originally described from a hatchery near to the Indalsälv river in Sweden (Malmberg 1957), Gyrodactylus salaris was not considered pathogenic in the wild, and it has since been recorded on several occa- sions within the Baltic watershed without being associated with disease (Malmberg \& Malmberg 1991, 1993). This led to the hypothesis that Norwegian salmon were particularly susceptible to this pathogen, and that $G$. salaris was a recent introduction into Norway (Johnsen \& Jensen 1991, Mo 1994). In support of this, Bakke et al. (1990) showed that 2 Norwegian stocks of salmon succumbed readily to the parasite in the laboratory, while the parasite was not pathogenic in Baltic salmon (the Russian Neva stock). Hybrids between Norwegian Imsa and Baltic Neva stocks showed intermediate susceptibility (Bakke et al. 1999, 2002). Further support for the anthropochore spread of $G$. salaris across national borders comes from the recent epidemic in a 
White Sea salmon stock in Russia, which is known to have been caused by introduction from Finland (Malmberg 1993, Mo 1994, Johnsen et al. 1999).

Introduction does not however fully explain the relative susceptibility of different salmon stocks to Gyrodactylus salaris. Detailed study has revealed a patchwork of pathogenicity, which does not reflect the Baltic/Eastern Atlantic split in salmon stocks (reviewed in Bakke et al. 2002). Although Bakke et al. (1990) did show a clear difference between Neva and 2 Norwegian salmon stocks during a 4 wk experiment, 3 further Eastern Atlantic stocks, 2 from Scotland and 1 from Norway (Lierelva), showed a range in susceptibilities, and some individual Norwegian fish were able to limit G. salaris infection (Bakke \& MacKenzie 1993). Subsequently, Jansen \& Bakke (1993a) showed that some wild Lierelva parr, individually constrained in the river throughout the year, could successfully control parasite population growth. Experimentally, Altaelva

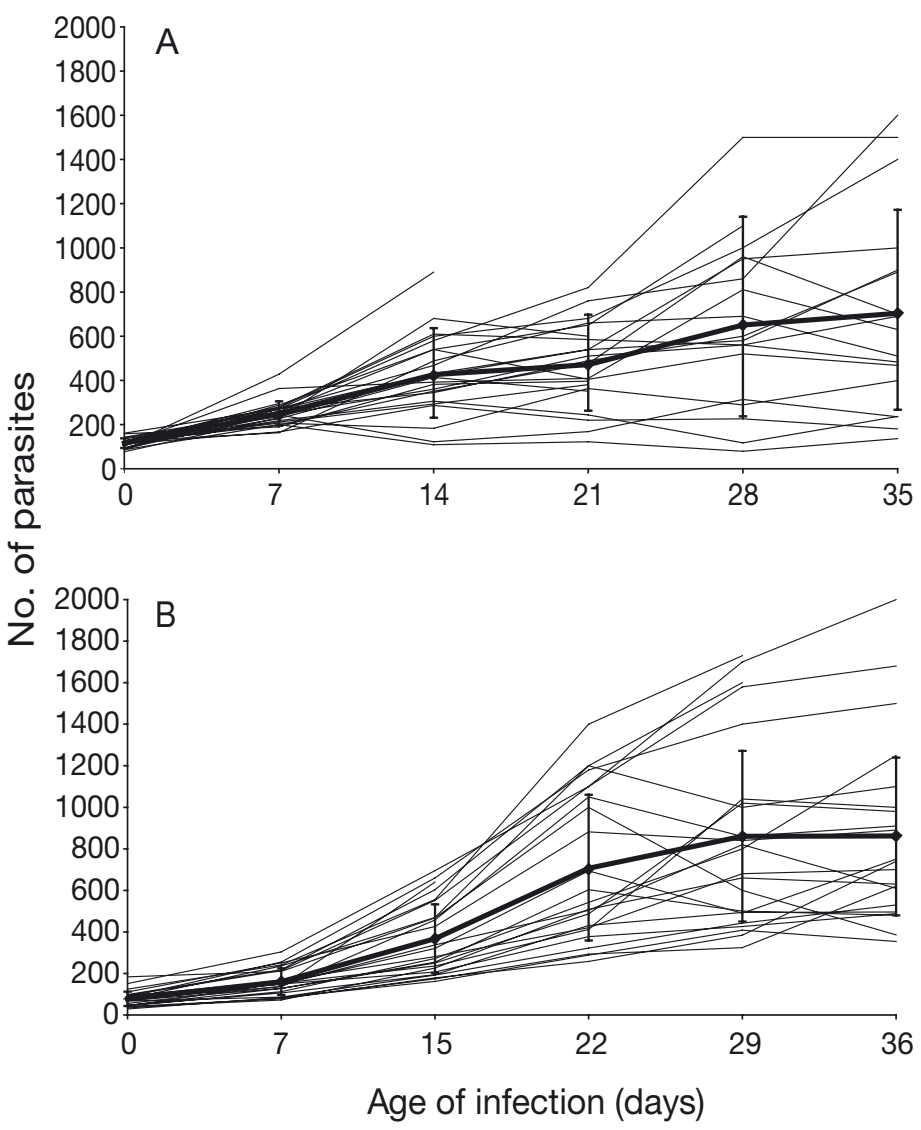

Fig. 1. Gyrodactylus salaris (Figga strain) infecting Salmo salar. Individual trajectories of infrapopulation growth of $G$. salaris on isolated salmon parr of (A) Indalsälv (Baltic) and (B) Lierelva (Norwegian) stock. Thick line: mean \pm 1 SD of natural logarithm-transformed data; fine lines: trajectories of parasite population growth on individual parr; lines terminating before Day 35 indicate mortality salmon parr have also mounted a response to $G$. salaris, with a decline in parasite population growth late in the infection (Bakke et al. 1999). There is therefore a previously unappreciated degree of heterogeneity of resistance within and between Norwegian salmon stocks.

Although several Norwegian salmon stocks have been assessed with respect to their susceptibility/resistance to Gyrodactylus salaris and recently 3 salmon stocks from the west coast of Sweden (Karlsson et al. 2003), only 2 Baltic stocks (Rivers Neva and Lule) have been tested in detail. All fish of the Neva stock mounted a host response (Bakke et al. 1990, 2002), whereas the Swedish Lule stock was susceptible, but to a lesser extent than a Scottish salmon stock (Dalgaard et al. 2003). This indicates that susceptibility to G. salaris might not be restricted to East Atlantic salmon. To further investigate the spectrum of specificity found in Baltic salmon stocks, we have therefore compared the susceptibility of the Indalsälv stock from the Baltic coast of Sweden with that of the extensively studied Lierelva stock from SE Norway (Jansen \& Bakke 1991, 1993a,b, Bakke \& Mackenzie 1993).

\section{MATERIALS AND METHODS}

Naïve Swedish salmon Salmo salar of the River Indalsälv stock, hatchery-reared from artificially spawned eggs, were obtained from Bergeforsens Kraft AB Laksodling, Sweden. The parr (average length/ weight of $9.1 \mathrm{~cm} / 5.4 \mathrm{~g}$ ) were transported to Vikan AkvaVet (Veterinary Station for Contract Research in Fish Diseases, Norway) in February 1992, and on arrival, conditioned for $1 \mathrm{wk}$ to a water temperature of $12^{\circ} \mathrm{C} \pm 0.5$, and an $8 \mathrm{~h}$ light: $16 \mathrm{~h}$ dark regime. The salmon $(n=150)$ were infected over $2 \mathrm{~d}$ by exposure to 10 killed and 35 living marked parr (River Namsen stock) that were artificially infected with the River Figga (central Norway) strain of Gyrodactylus salaris. This resulted in an epidemic spread of G. salaris, and all fish acquired infections (range 77 to 161 parasites). The experimental fish of each stock were then separated from the naturally infected fish (Day 0) and transferred to two 5001 holding tanks with a constantly flowing water supply of $51 \mathrm{~min}^{-1}$. Each tank held 50 fish in a pooled group plus another 12 fish individually isolated in small floating grey plastic cages $(47 \times 37 \mathrm{~cm}$, $10 \mathrm{~cm}$ water level) with wire-mesh floors. The pooled fish were fed unmedicated pellet food (EWOS), the isolated fish were unfed. At weekly intervals from Day 0, all isolated fish and 10 fish randomly selected fish from each pooled group were anaesthetized ( 2 min in $0.04 \%$ chlorobutanol), and the numbers of G. salaris counted using a stereomicroscope (intensities from 500 to 1000 
were counted to the nearest 10, and those over 1000 to the nearest 100). The above experimental procedures were identical to those of Bakke \& MacKenzie (1993), who assessed reproduction of the same parasite strain on Norwegian Lierelva parr 4 mo earlier at Vikan AkvaVet. The data from this study were re-analysed for comparison with the parasite growth on Swedish salmon.

Analysis of parasite populations was carried out using a natural logarithm transformation $\left(\log _{\mathrm{e}} \mathrm{N}+1\right)$ to confer normality. This was the most appropriate transformation in the absence of specific data on the value of $k$, the overdispersion coefficient. Analyses were performed using SPSS for Windows Version 11.0.

The reproductive rate ( $r$ ) of Gyrodactylus salaris on individual parr was calculated from the equation:

$$
\mathrm{N}_{t}=\mathrm{N}_{0} \mathrm{e}^{r t}
$$

where $\mathrm{N}_{t}=$ the number of parasites recorded at Time $t$, and $\mathrm{N}_{0}=$ the number of parasites recorded at Time 0 . Reproductive rates were normally distributed at each time point, allowing parametric statistics (Student's $t$-test and Pearson's correlation coefficient) to be applied without transformation.

\section{RESULTS}

The initial prevalence of Gyrodactylus salaris on both individually isolated and grouped Indalsälv and Lierelva fishes was $100 \%$ on Day 0. The initial intensity of infection varied between stocks, with the Indalsälv hosts being infected with 86 to 161 parasites (mean 115.9) and the Lierelva parr harbouring 29 to 184 parasites each (mean 77). This variation in parasite burden did not appear to influence the outcome of the infection. During the first week, parasite infrapopulations increased on all Indalsälv fishes, but heterogeneity was evident subsequently. Thus, on some Indalsälv hosts the parasite burden increased continuously throughout the infection, while on others the infrapopulations reached their peak size after a variable time period of up to $4 \mathrm{wk}$. Some Indalsälv fish controlled their infections at relatively low parasite burdens (200 to 300 worms fish ${ }^{-1}$ ) as early as 7 to $14 \mathrm{~d}$ post-infection, p.i. (Fig. 1). On isolated Lierelva parr, the initial pattern of parasite population growth was similar, with some infections increasing throughout the experiment. However, on some fishes, the G. salaris infrapopulations attained a peak intensity of ca. 800 parasites after 28 to $35 \mathrm{~d}$ and then declined (see Bakke \& Mackenzie 1993). Both stocks of fish also contained a small proportion of hosts on which parasite population growth continued until either the fish died or the experiment was terminated. Fewer Indalsälv parr (5 out of 24) were able to limit parasite reproduction compared to the Lierelva population (10 out of 24), and the proportion of fish on which the $G$. salaris population grew without check within the experimental period was correspondingly greater amongst the Indalsälv stock. However, the spectrum of individual host responses to the parasite was similar in the 2 salmon stocks.

Reproductive rate was calculated for each successive $7 \mathrm{~d}$ period. The average initial reproductive rate $(r)$ of Gyrodactylus salaris on Lierelva fish in this experiment was $0.1021(\mathrm{SD}=0.0499, \mathrm{n}=24)$, while that on Indalsälv fish was only $0.0825(\mathrm{SD}=0.0607, \mathrm{n}=24)$. This difference between initial reproductive rates (Fig. 2) was barely significant at the $\mathrm{p}>0.1$ level (1-tailed Student's $t$-test: critical value for $10 \%$ significance $=1.319$, calculated value for experimental data $=1.332$ ). However, even such a small difference can be important as population size increases as the exponent of $r$. The proportion of Indalsälv fish in which $r$ was initially negative was greater than the proportion for Lierelva fishes, and conversely the proportion of Lierelva fish with an initial rate of reproduction in excess of 0.15 was correspondingly greater (Fig. 2). On Lierelva fish, parasite population growth rates declined steadily, becoming negative on many (11 out of 24 ) hosts 30 to $35 \mathrm{~d}$ p.i. (Fig. 3). This decline in population growth rate was correlated with infection age (Pearson's $r=0.726$, $\mathrm{n}=$ $140, \mathrm{p}=<0.001)$, but not infection size. This pattern of decline in parasite population growth rate is typical of G. salaris infections on Norwegian salmon stocks (Bakke et al. 2002). On Indalsälv fish a similar trend of declining population growth rate was noted, with 13 out of 24 fish showing a negative rate after 30 to $35 \mathrm{~d}$, but the correlation between population growth rate and age of infection was not as strong (Pearson's

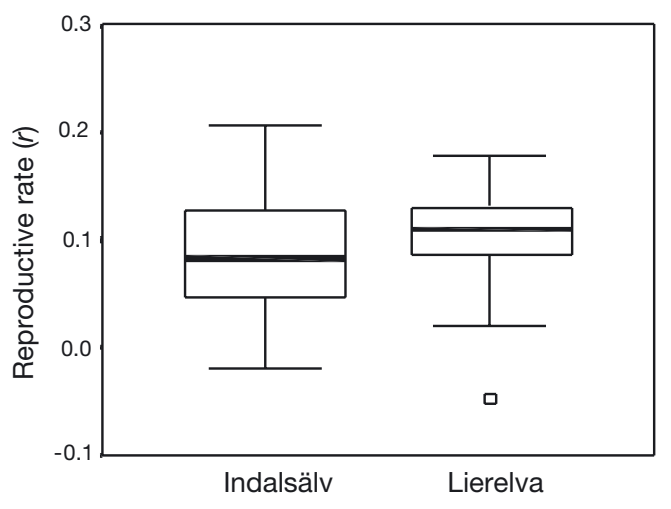

Fig. 2. Gyrodactylus salaris (Figga strain) infecting Salmo salar. Boxplots showing reproductive rate $(r)$ after $7 \mathrm{~d}$ for $G$. salaris on both Lierelva (Norwegian) and Indalsälv (Baltic) salmon parr. Boxes represent dispersion of data points up to $1 \mathrm{SD}$ of mean (marked by thick line); whiskers represent data points extending from mean \pm 1 variance; (a) outlier 
$r=0.4287, \mathrm{n}=103, \mathrm{p}<0.001)$. This was because many of the trajectories were curvilinear, with several declining rapidly in the first weeks after infection but then increasing again towards the end of the study period.

No significant differences (Student's $t$-test on means of $\log _{\mathrm{e}}$-transformed data) were noted in the population growth of Gyrodactylus salaris on Lierelva or Indalsälv shoals (Fig. 4), although in general populations

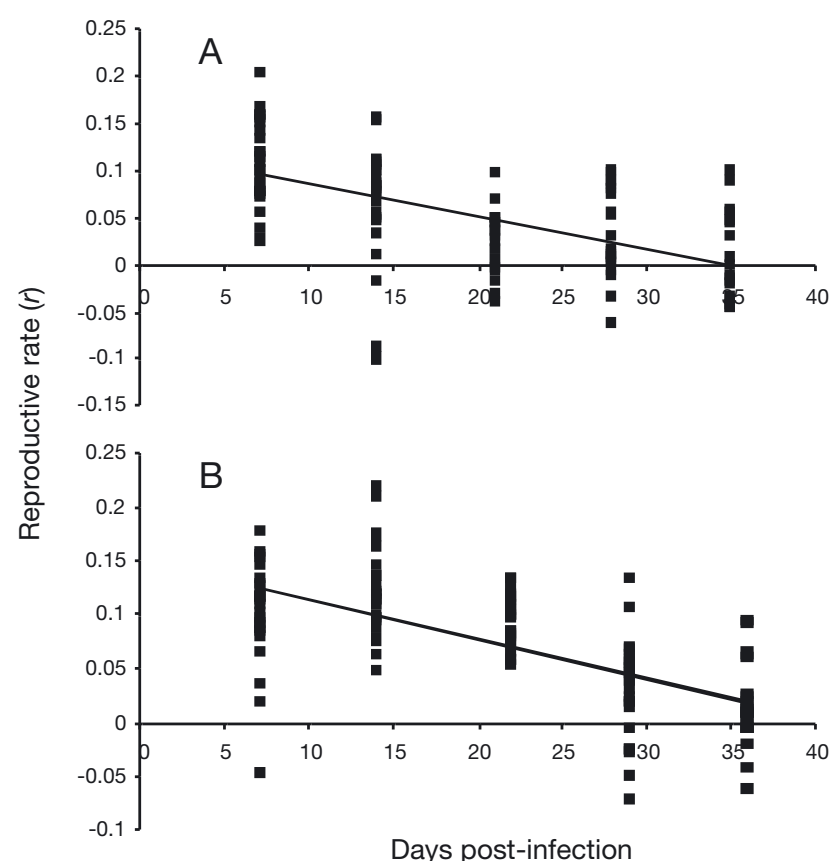

Fig. 3. Gyrodactylus salaris (Figga strain) infecting Salmo salar. Relationship between population growth rate of $G$. salaris on (A) Indalsälv (Baltic) salmon parr and (B) Lierelva (Norwegian) salmon parr and days post-infection

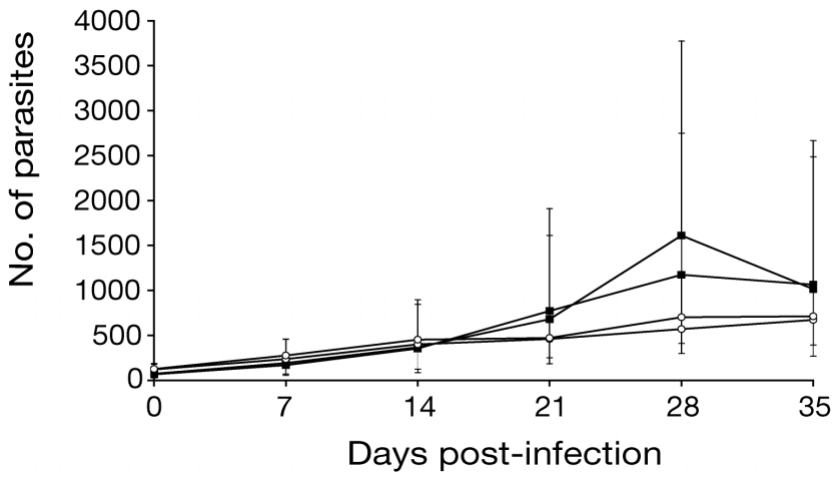

Fig. 4. Gyrodactylus salaris (Figga strain) infecting Salmo salar. Growth of G. salaris populations on shoaling populations of Lierelva (घ) and Indalsälv (o) salmon parr; 2 replicate populations of 50 fish examined for each salmon strain. Data points represent means \pm 1 SD of natural logtransformed data achieved a larger size after $35 \mathrm{~d}$ on the Lierelva fishes. G. salaris growth on the shoals continued throughout the infection with little evidence of a host response, although population growth on Lierelva fishes did slow $28 \mathrm{~d}$ p.i. In contrast, there was no evidence of declining population growth in the slower-growing G. salaris populations on Indalsälv parr (Fig. 4).

Mortality amongst individually isolated parr was similar for both salmon strains, with $30 \%$ of Indalsälv and $40 \%$ of Lierelva fishes dying within 35 d (Fig. 5). The onset of parasite-induced mortality occurred at 25 to $28 \mathrm{~d}$ p.i.

\section{DISCUSSION}

The present results show that the level of success of the parasite and the host mortality of the Indalsälv stock due to Norwegian Gyrodactylus salaris is comparable to that of the Norwegian stock from Lierelva (see Bakke \& MacKenzie 1993). This is surprising, as the Baltic salmon stocks have previously been regarded as resistant to G. salaris (Bakke et al. 1990, 2002), although Dalgaard et al. (2003) found that the Swedish Lule stock was susceptible to the Norwegian River Laerdalselva strain of G. salaris. During 1952 to 1956, Indalsälv was restocked with salmon of the Umeälv stock (Larsson et al. 1979). Since 1956, when a hydroelectric dam was constructed, natural reproduction of salmon in the river has ceased, and the population is totally dependent on annual restocking with offspring from a brood stock of only 25 to 30 native wild adults. In 1958 only 1 pair of adult salmon were used for restocking and the stock has therefore been severely bottlenecked. As a consequence, polymorphic diseaseresistance alleles may have been lost, resulting in reduced G. salaris resistance compared to the original

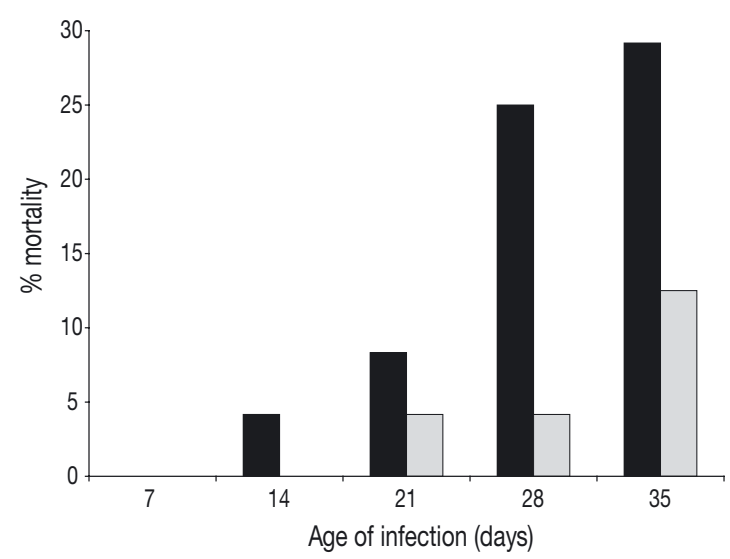

Fig. 5. Salmo salmar infected by Gyrodactylus salaris. Mortality of parr individually isolated after infection. Black bars: Indalsälv strain (Baltic); grey bars: Lierelva strain (Norwegian) 
Indalsälv salmon. However, we observed heterogeneity over the course of infection, and parasite population growth declined on some individually isolated salmon, suggesting that some genetic diversity may have been retained.

The initial growth rates of Gyrodactylus salaris populations on Indalsälv and Lierelva parr were similar, and consistent with the maximum rate calculated for this species (Jansen \& Bakke 1991, Harris et al. 1994, Cable et al. 2000, Bakke et al. 2002). The intrinsic population growth rate $(r)$ of $G$. salaris on individually isolated salmon parr of both stocks declined from the start of infection, but at different rates, and parasite populations began to decline after 28 to $35 \mathrm{~d}$. This pattern of decline in population growth rate suggests that in spite of the initial growth of infection on both salmon stocks, a response occurs from the start of infection before a decline is noticed (P. D. Harris et al. unpubl.), supporting observations that the host response is more closely related to infection age rather than size (Bakke et al. 2002).

In shoals of both salmon stocks, some Gyrodactylus salaris infrapopulations increased without check until the hosts died. This difference in the course of infection between individually isolated and pooled fish has been observed for other gyrodactylids (Lester \& Adams 1974, Scott \& Anderson 1984, Harris 1989) and may be related to transmission strategy. Parasites that are not killed by a host reaction may re-infect other hosts, and so, in the confined conditions of the experimental aquarium, populations may build up to lethal levels. During the present experiments, fish were not removed immediately after death but could lie on the tank bottom overnight; hence, reinfection by dislodged parasites (Bakke et al. 1991, 1992) may have been a major cause of the higher growth rate of G. salaris populations in the pooled fish. Immunity cannot control parasite population growth in homogenous environments unless it is synchronous in all fish. This was also shown in long-term infection by G. turnbulli of guppies (Scott \& Anderson 1984, Richards \& Chubb 1996), and only Oncorhynchus mykiss (see Bakke et al. 1991) and Salvelinus fontinalis (see Bakke et al. 1992) responded to G. salaris infection sufficiently synchronously to eliminate the infection. Mortality of individual salmon in natural environments due to G. salaris does not automatically imply a lack of an immune response in the fish concerned.

If the present results do represent the natural salmon susceptibility to Gyrodactylus salaris in Indalsälv, this either reflects variability in G. salaris susceptibility among Baltic salmon, and/or variation in parasite virulence, which is probably influenced by micro- and macro-environmental factors. Although ecological river conditions related to both water chemistry and water physics are known to influence the epidemiology of G. salaris (see Jansen \& Bakke 1991, Soleng et al. 1999, Bakke et al. 2002), no studies have been undertaken investigating the influence of macro-environmental factors on G. salaris epidemiology in the Baltic area.

Atlantic salmon stocks are well known to exhibit genetic variation. Thorpe \& Mitchell (1981), Ståhl (1987) and Ståhl \& Hindar (1988), using allozymes, found genetic differences between populations from rivers draining the East Atlantic and Baltic Seas. Recently, Nilsson et al. (2001), using mitochondrial markers, found the greatest genetic diversity amongst the Atlantic populations, followed by Baltic populations from the Gulf of Bothnia (including Indalsälv). Populations in the Southern Baltic (including Neva and most landlocked salmon) included only a single unique haplotype. One haplotype prevalent in a Norwegian stock (Numedalslågen, SE Norway) also dominated in the Indalsälv Baltic salmon, but differed markedly from that of the Neva stock (Nilsson et al. 2001). This indicates that stocks from the Gulf of Bothnia may be more similar to Norwegian stocks than to those from the Gulf of Finland. This could be important in explaining the present observed similarity of the Swedish and Norwegian stocks in their susceptibility to Gyrodactylus salaris. However, the extant geographical pattern of susceptibility may be very complicated, as populations in individual rivers may be affected to differing degrees by genetic drift and founder events, and disrupted by stocking and stock transfer both in and between Sweden and Norway (Larsson et al. 1979, Johnsen et al. 1999, Nilsson et al. 2001). Furthermore, many Baltic Sea salmon populations exist only as hatchery populations, with attendant inherent risks to their genetic integrity. It appears that a patchwork of resistance and susceptibility to G. salaris exists in salmon stocks from different rivers in the Baltic, as has previously been found for Norway (Bakke et al. 2002), and that absolute distinctions do not exist between the major East Atlantic and Baltic clades. This patchwork of susceptibility would also explain why salmon parr in some infected Norwegian rivers seem to survive better (Mo 1992, Jansen \& Bakke 1993b) than those in others (Johnsen \& Jensen 1991, 1992).

The biological diversity of Gyrodactylus salaris strains from the East Atlantic and the Baltic has not yet been tested. However, we have recently demonstrated significant molecular heterogeneity between different Norwegian populations of G. salaris (Hansen et al. 2003, J. Cable, P. D. Harris and T. A. Bakke unpubl.), which may also be reflected in biological differences in infectivity, virulence and pathogenicity. The present results indicate an urgent need to increase our knowledge concerning the potential for differences in viru- 
lence of G. salaris strains to East Atlantic and Baltic salmon.

In conclusion, these results show that the Indalsälv stock, a Baltic salmon generally assumed to be resistant to Gyrodactylus salaris, is almost as susceptible as Norwegian salmon under laboratory conditions, but appearing to possess a non-sterile immunity that can be epidemiologically effective when hosts are maintained at low density. The results indicate that outbreaks of gyrodactylosis can be due to stock variability in the susceptibility of both Atlantic and Baltic salmon stocks and/or strain differences in G. salaris virulence. Recently, a genetic G. salaris variant from Denmark on rainbow trout Oncorhynchus mykiss was shown by Lindenstrøm et al. (2003) to have a very restricted reproduction on Atlantic salmon. The current results have clear implications for management of the disease, as relative resistance/susceptibility of a stock cannot be assumed without experimental evaluation.

Acknowledgements. We thank Jonas Salin at Bergforsens Kraft AB Laxodling, Sweden, for providing the Baltic salmon stock and for his assistance with health requirements and preparing the fish for transport, Leif Knivstøen for supplying the River Lierelva salmon, Rolf Nordmo for facilities at the Vikan AkvaVet, Namsos, Tom Isachsen for technical assistance, and Anton Rikstad, StatensHus, Steinkjer, for collecting the naturally infected salmon parr. The work is funded by the Norwegian Research Council (Project 145861/720).

\section{LITERATURE CITED}

Alenäs I (1998) Gyrodactylus salaris på lax i svenska vattendrag och lax-problematiken på svenska västkysten. Vann 1:135-142 (in Swedish)

Bakke TA, Mackenzie K (1993) Comparative susceptibility of native Scottish and Norwegian stocks of Atlantic salmon Salmo salar L., to Gyrodactylus salaris. Fish Res 17:69-85

Bakke TA, Jansen PA, Hansen LP (1990) Differences in the host resistance of Atlantic salmon (Salmo salar) stocks to the monogenean Gyrodactylus salaris Malmberg, 1957. J Fish Biol 37:577-587

Bakke TA, Jansen PA, Kennedy CR (1991) The host specificity of Gyrodactylus salaris Malmberg (Platyhelminthes, Monogenea): the susceptibility of Oncorhynchus mykiss (Walbaum) under experimental conditions. J Fish Biol 39: 45-57

Bakke TA, Harris PD, Jansen PA (1992) The susceptibility of Salvelinus fontinalis (Mitchill) to Gyrodactylus salaris Malmberg (Platyhelminthes: Monogenea) under experimental conditions. J Fish Biol 41:499-507

Bakke TA, Jansen PA, Harris PD (1996) Differences in susceptibility of anadromous and resident stocks of Arctic charr to infections of Gyrodactylus salaris under experimental conditions. J Fish Biol 49:341-351

Bakke TA, Soleng A, Harris PD (1999) The susceptibility of Atlantic salmon (Salmo salar L.) x brown trout (Salmo trutta L.) hybrids to Gyrodactylus salaris Malmberg and Gyrodactylus derjavini Mikailov. Parasitology 119: 467-481
Bakke TA, Harris PD, Cable J (2002) Host specificity dynamics: observations on gyrodactylid monogeneans. Int J Parasitol 32:281-308

Cable J, Harris PD, Bakke TA (2000) Population growth of Gyrodactylus salaris (Monogenea) on Norwegian and Baltic Atlantic salmon (Salmo salar) strains. Parasitology 121:621-629

Dalgaard MB, Nielsen CV, Buchmann K (2003) Comparative susceptibility of two races of Salmo salar (Baltic Lule river and Atlantic Conon river strains) to infection with Gyrodactylus salaris. Dis Aquat Org 53:173-176

Hansen H, Bachmann L, Bakke TA (2003) Mitochondrial DNA variation of Gyrodactylus spp. (Monogenea, Gyrodactylidae) populations infecting Atlantic salmon, grayling, and rainbow trout in Norway and Sweden. Int J Parasitol 33:1471-1478

Harris PD (1989) Interactions between population growth and sexual reproduction in the viviparous monogenean Gyrodactylus turnbulli Harris, 1986 from the guppy, Poecilia reticulata Peters. Parasitology 98:245-251

Harris PD, Jansen PA, Bakke TA (1994) The population age structure and reproductive biology of Gyrodactylus salaris Malmberg (Monogenea). Parasitology 108:167-173

Heggberget TG, Johnsen BO (1982) Infestations by Gyrodactylus sp. of Atlantic salmon in Norwegian rivers. J Fish Biol 21:15-26

Jansen PA, Bakke TA (1991) Temperature dependent reproduction and survival of Gyrodactylus salaris Malmberg, 1957 (Platyhelminthes: Monogenea) on Atlantic salmon (Salmo salar L.). Parasitology 102:105-112

Jansen PA, Bakke TA (1993a) Regulatory processes in the monogenean Gyrodactylus salaris-Atlantic salmon (Salmo salar L.) association. 2. Experimental studies. Fish Res 17:103-114

Jansen PA, Bakke TA (1993b) Regulatory processes in the monogenean Gyrodactylus salaris-Atlantic salmon (Salmo salar L.) association. 1. Field studies in south-east Norway. Fish Res 17:87-101

Johnsen BO, Jensen AJ (1991) The Gyrodactylus story in Norway. Aquaculture 98:289-302

Johnsen BO, Jensen AJ (1992) Infection of Atlantic salmon, Salmo salar L., by Gyrodactylus salaris, Malmberg 1957, in the River Lakselva, Misvær in northern Norway. J Fish Biol 40:433-444

Johnsen BO, Møkkelgjerd PI, Jensen AJ (1999) The parasite Gyrodactylus salaris on salmon parr in Norwegian rivers, status report at the beginning of year 2000. NINA Oppdragsmeld 617:1-129 (in Norwegian, English summary)

Karlsson L, Kollberg S, Olstad K, Mo TA (2003) Känslighet hos lax från Enningdalsälven, Gullspångsälven, Rolfsån och Drammenselva för parasiten Gyrodactylus salaris i laboratorieforsök. Rapp Fiskeriverk länsstyrelsen Halland, 2003-01-16:1-31 (in Swedish)

Larsson PO, Larsson HO, Eriksson C (1979) Översiktlig bedöming av resultaten av märkningsförsök på ulika stammar av lax (Salmo salar L.). Salmon Res Inst Rep 5: 1-28 (in Swedish)

Lester RJG, Adams JR (1974) A simple model of a Gyrodactylus population. Int J Parasitol 4:497-506

Lindenstrøm T, Collins CM, Bresciani J, Cunningham CO, Buchmann K (2003) Characterization of a Gyrodactylus salaris variant: infection biology, morphology and molecular genetics. Parasitology 127:165-177

Malmberg G (1957) On the occurrence of Gyrodactylus on Swedish fishes. Skr Söd Sver FiskFör 1956:19-76 (in Swedish, English summary)

Malmberg G (1993) Gyrodactylidae and gyrodactylosis of 
Salmonidae. Bull Fr Pêche Piscic 328:5-46

Malmberg G, Malmberg M (1991) Investigations for Gyrodactylus on salmonids in natural waters and fish farms during the periods 1951-72 and 1986-May 1991. Inf Söttvattenslab Drottingholm 2:1-30 (in Swedish, English summary)

Malmberg G, Malmberg M (1993) Species of Gyrodactylus (Plathyhelminthes, Monogenea) on salmonids in Sweden. Fish Res 17:59-68

Mo TA (1992) Seasonal variations in the prevalence and infestation intensity of Gyrodactylus salaris Malmberg, 1957 (Monogenea: Gyrodactylidae) on Atlantic salmon parr, Salmo salar L., in the River Batnsfjordselva, Norway. J Fish Biol 41:697-707

Mo TA (1994) Status of Gyrodactylus problems and research in Norway. In: Pike AW, Lewis JW (eds) Parasitic diseases in fish. Samara, Tresaith, UK, p 43-58

Nilsson J, Gross R, Asplund T, Dove O and 12 others (2001) Matrilinear phylogeography of Atlantic salmon (Salmo salar L.) in Europe and postglacial colonization of the Baltic. Mol Ecol 10:89-102

NOU (Norges Offentlige Utredninger) (1999) Til laks åt alle kan ingen gjera? Om årsaker til nedgangen i den norske villaksbestandene og forslag til strategier og tiltak for å bedre situasjonen. Utredning fra et utvalg oppnevnt ved

Editorial responsibility: Wolfgang Körting,

Hannover, Germany kongelig resolusjon av 18. juli 1977. Norges Offentlige Utredninger, Miljøverndepartementet 1999, p 1-297 (in Norwegian)

Richards G, Chubb JE (1996) Longer-term population dynamics of Gyrodactylus bullatarudis and G. turnbulli (Monogenea) on adult guppies (Poecilia reticulata) in 50-1 experimental arenas. Parasitol Res 84:753-756

Scott ME, Anderson RM (1984) The population dynamics of Gyrodactylus bullatarudis (Monogenea) within laboratory populations of the fish host Poecilia reticulata. Parasitology 89:159-195

Soleng A, Poléo ABS, Alstad NEW, Bakke TA (1999) Aqueous aluminium eliminates Gyrodactylus salaris (Platyhelminthes, Monogenea) infections in Atlantic salmon. Parasitology 119:19-25

Ståhl G (1987) Genetic population structure of Atlantic salmon. In: Ryman N, Utter R (eds) Population genetics and fishery management. University of Washington Press, Seattle, p 121-140

Ståhl G, Hindar K (1988) Genetic structure in Norwegian salmon: status and perspectives. Rapp FiskeForsk 1988 (1):1-57 (in Norwegian)

Thorpe JE, Mitchell KA (1981) Stocks of Atlantic salmon (Salmo salar) in Britain and Ireland: discreteness and current management. Can J Fish Aquat Sci 38:1576-1590

Submitted: January 28, 2003; Accepted: November 5, 2003 Proofs received from author(s): February 9, 2004 